\title{
Archeological Assessment of Historic and Prehistoric Sites Alone U.S. 87 Sterling County, Texas
}

Nancy A. Kenmotsu

John W. Clark, Jr.

Daymond Clark

Follow this and additional works at: https://scholarworks.sfasu.edu/ita

Part of the American Material Culture Commons, Archaeological Anthropology Commons, Environmental Studies Commons, Other American Studies Commons, Other Arts and Humanities Commons, Other History of Art, Architecture, and Archaeology Commons, and the United States History Commons

Tell us how this article helped you.

This Article is brought to you for free and open access by the Center for Regional Heritage Research at SFA ScholarWorks. It has been accepted for inclusion in Index of Texas Archaeology: Open Access Gray Literature from the Lone Star State by an authorized editor of SFA ScholarWorks. For more information, please contact cdsscholarworks@sfasu.edu. 


\section{Archeological Assessment of Historic and Prehistoric Sites Alone U.S. 87 Sterling County, Texas}

\section{Licensing Statement}

This is a work produced for the Texas Department of Transportation (TxDOT) by the report producer. TxDOT and the report producer jointly own all rights, title, and interest in and to all intellectual property developed under TXDOT's contract with the report producer. The report may be cited and brief passages from this publication may be reproduced without permission provided that credit is given to both TXDOT and the report producer. Permission to reprint an entire chapter, section, figures or tables must be obtained in advance from either the Supervisor of the Archeological Studies Branch, Environmental Affairs Division, Texas Department of Transportation, 125 East 11th Street, Austin, Texas, 78701 or from the report producer. 


\title{
Archeological A ssessment of Historic and Prehistoric Sites \\ Along U.S. 87 \\ Sterling County, Texas
}

\author{
by \\ Nancy A. Kenmotsu \\ John W. Clark, Jr. \\ and \\ Daymond Crawford
}

1997

\section{Archeology Studies Program \\ Cultural Resource Management Section \\ Environmental Affairs Division Texas Department of T ransportation}




\section{Table of Contents}

Management Summary …......................................................................................................... vii

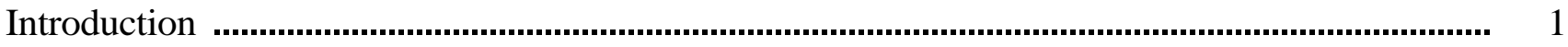

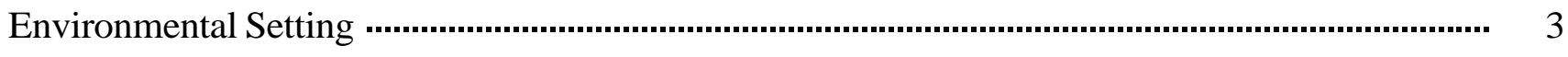

Cultural Setting ....................................................................................................................... 5

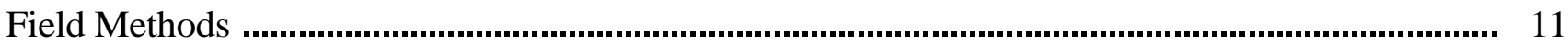

Results of the Investigations

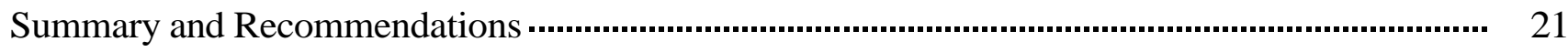

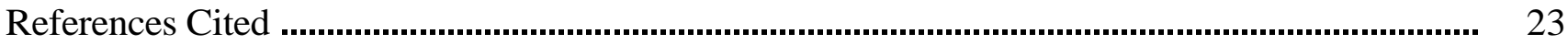

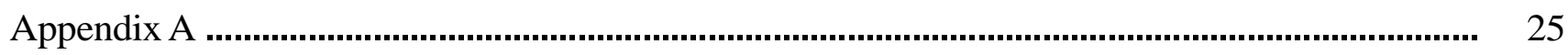




\section{List OF Figures}

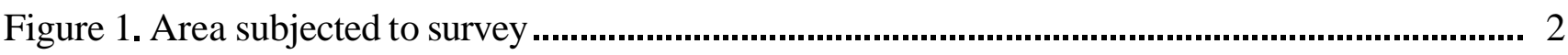

Figure 2. Emblem of the Tenth Regiment. United States Cavalry ..................................................... 7

Figure 3. Sketch map of the Camp on the North Concho .............................................................. 7

Figure 4. 1875 map of trails leading west from Fort Concho ....................................................... 8

Figure 5. View of the Camp on the North Concho as it appears today.............................................. 9

Figure 6. The 1936 State of Texas Centennial Marker ................................................................... 9

Figure 7. Mapping Feature 1 at the Camp on the North Concho....................................................... 11

Figure 8. 1954 aerial of the area of the Camp on the North Concho ................................................ 14

Figure 9. Map of the Camp on the North Concho within U.S. 87 right of way ................................. 15

Figure 10. 1996 aerial photograph of the Camp on the North Concho ........................................... 16

Figure 11. Map of Feature 1 ................................................................................................................. 17

Figure 12 . Map of Feature 2 ................................................................................................................ 18

Figure 13. Artifacts collected from the Camp on the North Concho................................................. 18 


\section{Management Summary}

One prehistoric and one historic archeological sites were identified during investigations carried out in February and March 1997 along U.S. 87 in Sterling County, Texas. The prehistoric site has been concluded to not be eligible for inclusion in the National Register of Historic Places and is not recommended for further work. The historic site, the Camp on the North Concho, was occupied from the 1850s through 1886. Used as a camp for the Texas Rangers and later the U.S. Army, the site is considered eligible for the National Register under criteria A and D. Mitigation of the proposed project's effects upon the camp are recommended to focus on three research topics: 1) determination of whether the camp was used by the Texas Rangers, 2) the role of the camp as an outpost for forts Chadboume and Concho during the period of westward settlement, and $\mathbf{3}$ ) the training and duties of the Buffalo Soldiers at the camp.

Archival and archeological investigations will be needed to conduct the research for these three goals. Specifically, the following tasks are recommended:

Archeological Mitigation: Obtain a representative sample of the artifactual material at the camp and create an improved base map:

A. Mapping the portion of the camp in the right of way.

B. Excavating $50 \times 50 \mathrm{~cm}$ units in the southwest comer of each of the gridded units, screening and collecting all artifacts as a single unit.

C. Excavating four $50 \times 50 \mathrm{~cm}$ units at Feature 1 to confirm its use (or not) as the farrier's shop.

D. Analyzing, conserving and curating all artifacts, in accordance with the standards and requirements of Fort

Concho National Historical Site.

E. Monitor construction to identify and record features on site map.

Archival Mitigation: Obtain documentary information on the role of the camp as an outpost for two historic forts and the training of Buffalo Soldier troops at the site, and to determine if the camp was used by the Texas Rangers. The archival effort will require completion of the following tasks.
A. Investigate materials on the Texas Rangers at the Texas State Archives.
B. Investigate the Hunt and Grierson papers on file at Fort Concho.
C. Investigate materials from the National Archives (Fort Worth and Washington, D.C.) related to forts Concho and Chadbourne and the camp. The effort would also be concerned with general information about the Buffalo Soldiers.

At the conclusion of the archival and archeologicalinvestigations, a report detailing information related to the occupants of the camp, the training carried out at the camp, and the role of the camp and the Buffalo Soldiers in maintaining and sustaining westward expansion in Texas will be completed. Copies of the report will be provided to the Texas Historical Commission, Fort Concho, Fort Davis, Fort Clark, Fort McKavett, the Institute of Texan Cultures and the State Library. Finally, a brochure on the camp and its role in Texas history will be developed in consultation with the staff of Fort Concho National Historical Site. 


\section{INTRODUCTION}

Archeological investigations were undertaken along U.S. 87 in Sterling County by archeologistsfrom the Environmental Affairs Division of the Texas Department of Transportation (TxDOT) with the assistance of TxDOT's San Angelo District Office. The effort included identification and assessment of cultural resources that would be impacted by the proposed widening of approximately three miles of U.S. 87 beginning 4.6 miles northwest of State Highway 163 in Sterling County (Figure 1). The investigations were carried out as part of TxDOT's efforts to identify historic and prehistoric properties eligible for the National Register of Historic Places (National Register) that might be affected by the undertaking.

Highway enhancements of U.S. 87 have been progressing northwest from State Highway 163. They consist of upgrading approximately 42.2 kilometers (26.4 miles) of the present two-lane roadway to a four-lane divided highway in Sterling and Glasscock counties. Today, the two-lane portion of U.S. 87 in Sterling County has two 3.7- meter traffic lanes with 3.0- meter shoulders, while the Glasscock County section has two 4.8 -meter traffic lanes and 2.4- meter shoulders. The proposed action would eliminate the only remaining gap of two-lane roadway on U.S. 87 between San Angelo and Lubbock. In Sterling County, the proposed northbound main lanes would provide an 11.4- meter design cross section with two 3.6- meter travel lanes and 4.2- meter shoulders. The existing two-lane highway will remain and be utilized as the southbound main lanes. In places, 3.6- meter acceleration and deceleration lanes will be built. The proposed median would be flush with a width that will vary between 14.4 and 22.8 meters throughout the length of the project.

Additional right of way is required throughout the length of the project to accommodate the proposed widening. Right-of-way acquisition has been completed and consists of an additional 30.5 to 45.7 meters on the north side of the existing facility. The total proposed project will include the construction of 33 bridge class structures and 28 drainage structures (culverts), one of which will be included in this segment. Cuts and fills will also be involved with right-of-way preparation. No detours or special easements will be placed outside the new right of way.

In 1996, the department's professional archeological staff performed an archeological survey on the first segment of the proposed project from SH 163 northwest 4.6 miles (Henderson 1996). Seven archeological sites were identified; none were found eligible for the National Register. This report addresses the next three miles of the project. It includes a brief discussion of the environmental and cultural setting of the proposed project, and describes the archeological sites identified in the course of this effort.

In the present effort, two archeological sites were identified and assessed for their significance (see Figure 1). One of the sites (41ST110) is a prehistoric lithic scatter that is surfacial in nature and not recommended for the National Register or for designation as a State ArcheologicalLandmark. No further work is recommended for this site. One historic site was also identified and recorded, the Camp on the North Concho, often called Camp Elizabeth and recorded as archeological site number 41ST111. This camp was an outpost of Fort Chadbourne and laterFort Concho from the 1870s to 1886, and appears to have served as a Texas Ranger encampment prior to the Civil War (Daniels 1976). Exemplifying the frontier posts that sought to maintain the United States' hold on lands long claimed by native peoples, and as one of the outposts occupied by AfricanAmerican soldiers who came to be known as Buffalo Soldiers (Leckie 1967), the Camp on the North Concho meets Criteria A and D for the National Register. Recommendations for mitigating the effects of the widening of U.S. 87 on this site are incorporated into the final section of this report. 
This Page Redacted Per THC Policy 


\section{E'NVIRONMENTAL SETTING}

Sterling County is in the western portion of the Edwards Plateau physiographic region(Sellards 1936; Barnes 1976). The Edwards Plateau is characterized by a dissected topography with grasses on level to gently sloping landforms. Where topographic relief is greater, soils and grasses are minimal to absent. Geologic outcrops along the proposed project right of way belong to the Cretaceous Age (Barnes 1976). Limestone formations that once covered the area appear now as exposed bluffs with flat plateaus and limestone rubble hills. These formations are part of the undifferentiated E dwards/Comanche Peak/Walnut group that have resisted the erosion that the surrounding lands have undergone. These formations contain chert cobbles, frequently in relative abundance, that were utilized by prehistoric peoples to fashion various stone tools during the last 10,000 years (Treece et al. 1993:3-5). The limestone was also used by the soldiers at the Camp on the North Concho as building material for their structures.

The project area is nearly level to undulating. It parallels the North Concho River (see Figure 1) which, at this point, is small and intermittent. Throughout the project, the land surface slopes slowly upward from the riverbank to the limestone hills that dominate the horizon to the northeast. The project crosses several small, unnamed, intermittent streams and erosional cuts that have etched their way across the proposed project right of way from the limestone hills and terminate in the North Concho River. Among these are North Concho Draw, Cannibal Draw, Gardner Draw, Wade Draw, McEntire Draw, Willow Draw and Chalk Draw. McEntire Draw is within the segment of the project surveyed during this effort.

The vegetative regime of the proposed project is part of the Live Oak-Mesquite Savanna of the northwestern Edwards Plateau (Diamond et al. 1987), part of the lower Great Plains physiogeographicregion. However, highway maintenance and recent right of way fence relocation has reduced vegetation inside the proposed project right of way to short native grasses, cleared of trees and brush. Due to the mean annual rainfall of 18.38 inches, frequent droughts and overgrazing by livestock, the vegetation along U.S. 87 is sparse and scattered. Larger examples of vegetation are found along the fence lines, outside the proposed right of way. There, mesquite, juniper, cedar elm and hackberry trees are present. Black brush, creosote brush, catclaw, yucca,sotol and prickly pear cactus dominate the low vegetation. Current land use along the project right of way is agricultural in nature.

The soil survey of Sterling County (Blum 1977) depicts the soils within the proposed project right of way as the Angelo-Rioconcho-Broome association. These soils are deep, gently sloping, moderately to slowly permeable, loamy soils, and found on uplands and bottom lands. Limited areas of the Ector association are also represented. The Ector association is very shallow, gravelly, moderately permeable, on unduating to hilly terrain and are classed as loamy upland soils.

Angelo silty clay loam is a deep, nearly level soil on uplands that formed in calcareous, clayey and loamy sediments from ancient stream terraces. Slopes average about 0.7 percent. The surface layer is about 14 - inches thick. The upper 8 inches is friable, moderately alkaline, grayish brown silty clay loam. The lower 6 inches is a friable, moderately alkaline, brown clay loam. Between depths of 14 and 29 inches, the soil is a firm, moderately alkaline, brown clay loam, underlain by a friable, moderately alkaline, pink silty clay loam that contains 4050 percent weakly cemented concentrations of calcium carbonate.

Broome silty clay loam is a deep, gently sloping soil on uplands found on valleys edges and draws. These soils formed in calcareous, loamy sediments of ancient outwash and eolian deposits. Slopes average about two percent. This soil has a surface layer of friable, moderately alkaline, brown silty clay loam about 7 - inches thick, underlain by a friable, moderately alkaline, brown silty clay loam that extends to a depth of 18 inches. Between 18 and 39 inches, the soil is friable, moderately alkaline, light brown silty clay loam that contains about 30 percent calcium carbonate concentrations. Between depths of 39 inches, the soil is friable, moderately alkaline, reddish yellow silty clay loam that contains ca. 28 percent calcium carbonate.

Rioconcho silty clay loam consists of deep, loamy soils present on floodplains of streams that are occasionally flooded by runoff from adjacent slopes. These soils formed in calcareous clay and loamy alluvial sediments. This soil has a surface layer of firm, moderately alkaline, grayish brown silty clay loam about 16- inches thick, underlain by a firm, moderately alkaline, brown siltyclay that extends to a depth of about 42 inches. To a depth of 78 inches, the soil is firm, moderately alkaline, brown silty clay that contains films, threads and soft bodies of calcium carbonate. Below 78 inches the soil is a friable, moderately alkaline, pinkish gray clay loam.

At one time the region contained antelope, black bear, lesser prairie chicken, buffalo and prairie dogs (Barnes 1974:62). Bison were also present until the late 19th century (Bamforth 1987; Creel 1990). Deer, turkey, raccoon, ringtail cat, rabbits, squirrel and a variety of birds were plentiful along the drainages. Most of these species were deeply affected by Anglo-American settlement of the region in the 19th century, however, and today only a few remain as viable populations. 


\section{Cultural Setting}

The following is a brief overview of the prehistory of the western Edwards Plateau as background for interpreting sites 41ST110 and 41ST 111. It is followed by a more extended discussion of the Euro-American occupation of Texas and the historic Indian settlement of the project region. The latter discussion provides a context for the role of the Camp on the North Concho (41ST111) in Texas history and for the recommendations to mitigate the effects of the undertaking on this historic site.

Prior to the arrival of the Spanish in the late 16th century, the Rolling Plains region was occupied by hunters and gatherers whose nomadic lifestyles are recorded in scatters of artifacts frequently found in association with small hearths (campfires), burned rock accumulations where vegetal foods may have been prepared, and occasional cairn or crevice burials (Creel 1990; Treece et al. 1993; Johnson 1994). The earliest hunters and gatherers, known as Paleoindians, have left scant evidence of their passing. However, where present, these early sites have stone tools and, in some cases, animal remains that reflect an emphasis on hunting large game (Black 1989; Collins 1997). Around 6500 B.C., a new set of stone toolsbifacial knives, chipped axes and adzes, scrapers and grinding stones, coupled with barbed dart points-replace the Paleoindian toolkit and "reflect an emphasis on a more sedentary, collecting way of life" (Johnson and Goode 1994:19). The period when these tools were manufactured is known as the Archaic, a period that continued in the region until ca. A.D. 600 (Johnson and Goode 1994:39).

After A.D. 600, stone artifacts were dominated by end scrapers, bifaces, drills and small stemmed or side-notched arrow points (e.g., Scallorn, Perdiz and Washita), indicating a shift in technology to the use of wooden bows. Ceramics were never numerous, but appear to be locally made utilitarian wares, often small globular jars. Many of these sites contain large quantities of fauna. Bison often predominate such collections, such as at the Currie site (41CC131) at O.H. Ivie Reservoir where 11 percent of the fauna were from at least five individual bison (Treece et al. 1993:294). Some of these later peoples built small structures, as found at the Buckhollow site (41KM16) in Kimble County (Johnson 1994:228-230). A wall trench and bone peg alignments at the Rocky Branch site (41RN169) in Runnels County, and a similar wall trench at the Cume site (41CC131) in Concho County demonstrate that small circular structures were also constructed by these people at their camps along the Concho and Colorado rivers. A recent synthesis of these late sites by Johnson (1994) concludes that they represent the remains of nomadic peoples who lived in small groups, perhaps as extended families, and moved frequently within a restricted local area.

At the beginning of the 17th century, the Spanish who, by then, occupied Coahuila and Nueva Vizcaya, were moving into New Mexico (Jones 1988). Prior to 1689 , the Spanish made only sporadic forays into what is today Texas, but their impact on the native cultures was profound. In 1583, a native group known as the Jumanos were present between the Pecos and Concho rivers of Texas (Hammond and Rey 1929; Kenmotsu 1994). A century later, the Jumanos pleaded with the Spanish in El Paso to travel with them to their homelands to aid in their ongoing battle with the Apaches (AGN 1683). The Apaches, seeking to replace the Jumanos and other plains Indians with whom they competed for the Spanish trade in animal skins, horses and captives, were Athapaskan speakers from the northern plains (Opler 1983:368).

The Apache hold on the Southern and Rolling Plains was shortlived. In 1706, another name entered Spanish documents for the first time: Comanches (Kavanagh 1986:178).It was a name that quickly came to be both respected and feared by Indians, Spaniards and later, other European settlers. By the mid-18th century, these newcomers had smashed the Spanish-Apache relationship and won claim to the lands south of the Arkansas River (Kavanagh 1986:60). Until 1875, the Comanche remained the dominant Native American group on the Southern and Rolling Plains-an area that came to be known as Comancheria.

The Comanche were nomadic, living in temporary encampments for one to several months (Kavanagh 1986:47). Some large camps, under particularly skilled leaders, developed, endured for several generations, were loosely associated with a distinct part of Comancheria, and came to be known by a specific name (e.g., Kotsoteka, Penateka, etc.). Membership in the large bands could, and often did, change, and band names associated with general regions fluctuated as the bands formed and broke apart. Thus, in the late 18th century, the Kotsoteka (meaning "buffalo eaters") band dominated an enormous temtory stretching from the Pecos River to the Cross Timbers near modem Fort Worth, and from the Arkansas River to Del Rio, a region that includes modem Sterling County (Kavanagh 1986: 282). By the mid-19th century, the Kotsoteka had fragmented into several bands. While the region around Fort Concho and 41ST111 was still occupied by the greatly reduced Kotsoteka, the territory east of San Angelo was the domain of the Penateka Comanche (Kavanagh 1986:283-285).

T h r o u gthme, the Comanche hold on the Rolling Plains was as tenuous as that of their Apache forerunners. A nglo-A mericasettlement of the State began in earnest in 
1836, and a decade later citizens of the Republic of Texas sought annexation to the United States. In part, annexation was to ensure the U.S. Army would protect settlements from Indian and Mexican raids. Because the new state "held that neither Indians nor the United States had any rights to land in the public domain of Texas" (Saunders et al. 1991:105), a clash between the settlers and the Comanches was inevitable. On the one hand, the land west of San Antonio, Fredericksburg and Waco was available for settlement, but on the other hand, the Comanche considered it home. To maintain peace, the Army constructed two lines of Indian frontier forts beginning in 1849 , one, along a north-south line of settlements and the other along the Rio Grande. The forts were Martin Scott, Inge, Graham, Groghan, Worth, Lincoln and Gates.

However, settlements soon passed this line of forts, and a second line that included Fort Chadbourne was established beginning in 1851. Construction of the second line continued through 1856. Although designed to be one of this line of forts, Fort Concho was not built until after the Civil War (Taniguchi, Graham and Hamblett n.d. 8-10).

In 1855, a reservation was established for the Comanches on the Clear Fork of the Brazos, ca. 130 miles northeast of the Camp on the North Concho (Rister 1986: 17). However, although most Penatekas were moved into the reservation, the remaining Kotsoteka, the Kiowa and other native groups maintained their nomadic lifestyle and the reservation closed in 1859. Some Comanches moved to the Wichita Reservation in Oklahoma, but this relocation too was unsuccessful, and Comanche raids in both Texas and Mexico continued.

The Army staffed its forts with infantry companies. Settlers in the western portion of the state, believing that these companies were ineffective in preventing raids, pressured the government for more effective protection and lobbied to reinstate the ranging system, a system of state-paid rangers recruited by a leader to patrol and undertake expeditions against raiding Indians. Buck Barry, one of the Texas Ranger commanders, commented on the Army's ineffectiveness:

Neither the dragoons on their big and awkward chargers nor the infantry understood how to fight the Comanches. This fact the Indians soon learned and they became so active that the people began to call for someone who could cope with them. The regulars generally did not know the country and the redskins would lead them over hill and dale until the troops and their mounts were exhausted (quoted in Hardin and Hook 1991:20).

By 1852, six Texas Ranger companies had been called, and additional companies were added in 1854 . Some companies served on the Mexican border; the remainder served on the Indian frontier. The Rangers were tasked to remove the Indians and to make the western parts of the state safe for settlers. With the gold rush attracting thousands of emigrants to the southern route through Texas to the California gold fields, the rangers and Army were also charged with the safekeeping of those travelers. The Rangers provided their own guns, horses, tack and food. They were commissioned for relatively brief periods of time, typically as long as there was state funding. The Rangers were a highly effective, if undisciplined,force. By the 1850s, they had become legendary (Webb 1965).

With the secession of the southern states in 1861 , federal commanders in Texas surrendered their forts to the Confederacy, removing the troops and officers who did not wish to stay. The forts they left behind were occupied by Rangers or state troops during the war, often on an intermittent basis (Taniguchi et al. n.d.:10). In June 1865, federal troopsentered Texas as an army of occupation. However, not until November of 1866 did Federal troops occupy the frontier forts. The Army then completed its line of forts with the construction of Fort Concho in 1867. By the middle 1870s, troops from the fort began to occupy the Camp on the North Concho (Dearen n.d: 127). These troops soon came to be called "buffalo soldiers," AfricanAmericans who joined the U.S. Army after the war as an option to escape the poverty of rural life.

During the Civil War, African Americans served on both sides, as soldiers and as laborers. Those who served the Union became heroes to later generations. There were several African- American infantry regiments that served in the northern army; many were ill-used by their generals (Leckie 1967:1-6). They had, however, served well and were recommended for further service. In the south, African Americans, newly freed and without means of economic support, saw military service as a viable way to make a living. Since the federal government had an army heavy with officers but short on men to serve on the Indian frontier, creation of two African-American cavalry regiments and an oneinfantry regiment seemed an ideal solution.

The initial moves to create African-American regiments took place late in 1866. Edward Hatch and Benjamin Grierson were selected as the generals for the 9th and 10th Calvary (Leckie 1967:7-8). When the regiments were created and sent to their posts in Texas, however, few Texans welcomed black men in blue uniforms. Nonetheless, they came, and their fighting abilities and physical characteristics became so renowned among the Indians, that the Indians dubbed them "buffalo soldiers" (Leckie 1967:25-26), and the regimental crest includes a buffalo (Figure 2).

Anglo-American settlement of the North Concho River lands began during the period of Comanche turmoil that preceded the Civil War. According to unsubstantiated legend, it was during this period that the Camp on the 
North Concho, later named Camp Elizabeth by local ranchers, was established (Dearen n.d.: 123, Daniels 1976:5). One account (Dearen n.d.) has B arry's company of Rangers camping at or near the site of the future Camp on the North Concho where they had a small affray with the Comanches. During the Civil War, the camp is reputed to have been home to a Company of Texas

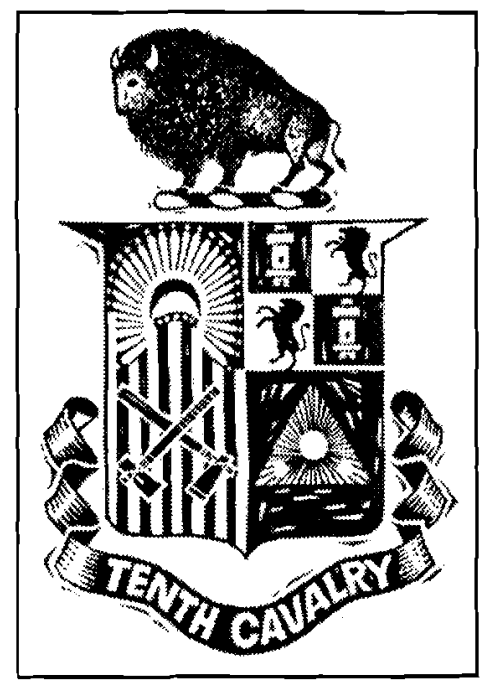

Figure 2. Emblem of the Tenth Regiment, United States Cavalry, with a buffalo (from the holdings of the National Archives).

Rangers until 1865.

After the Civil War, it

was intermittently occupied by African-American troops of the 10th Cavalry as an outpost of Fort Concho. These same troops had joined elements of the 9th in Texas and constructed Fort Concho in 1867.

At the Camp on the North Concho, structures were constructed around an ample parade ground used for horseback drill. Among the structures noted for the camp were officers' quarters, a hospital, a famer shop and rock corrals (Daniels 1976: 5). A sketch of the fort (Figure 3) as remembered by a former county surveyor includes additional structures consisting of a sutler's store, a kitchen and other buildings with tents for the enlisted men (Daniels 1976: 6). Companies were sent most likely to the camp on a temporary basis for annual training. An 1875 map (Figure 4) of the region indicates that the camp was located on a well-know trail moving northwest of Fort Concho.

All was not well at Fort Concho or at the Camp on the North Concho. Local inhabitants resented AfricanAmerican troops stationed among them (Dearen n.d.), believing these troops were punishment for their support of the Confederate cause. There appear to have been fights and murders, both at the fort and at the camp.

Apart from the difficulties between Texans and the Buffalo Soldiers, Indians remained a problem until 1875 when the United States established a new Comanche Reservation on land around Fort Sill on Cache Creek in southwestern Oklahoma (Kavanagh 1986:168).Although there were accounts of intermittent Comanche raiding and buffalo hunts into Texas after the settlement of Comanches on the reservation, they were few. However, the Camp on the North Concho continued to be used until approximately 1886, partly to repell Apache raids from the west. The last major Indian activity was in present-day Culberson County, when troops of the 10th Cavalry turned back Mescalero Apaches under Victorio. Victorio's band was subsequently caught by Col. Joaquin Terrazas (Terrazas 1973).

After 1886, the Army abandoned the Camp on the North Concho, and its buildings were incorporated into a local ranch (Dearen n.d.: 130) where they became a hangout for drifters. The ranch owner destroyed the roofs of the buildings and allowed stones used in their construction to be hauled off. Over the years, legends of treasure have sprung up and may have further contributed to the removal of stones from the buildings. Today, the visible remains of the Camp consist of the foundations of the buildings, some of which are marked by only a few pieces of shaped limestone (Figure 5) and a 1936 State of Texas Centennial Marker (Figure 6).

Archeological interest in the Camp on the North Concho developed with a December 1976 visit by members of the Concho Valley Archeological Society and Midland ArcheologicalSociety during which measurements were taken of the foundations visible at that time. Subsequent archeological interest has centered on the proposed activities of the Texas Department of Transportation on U.S, 87.

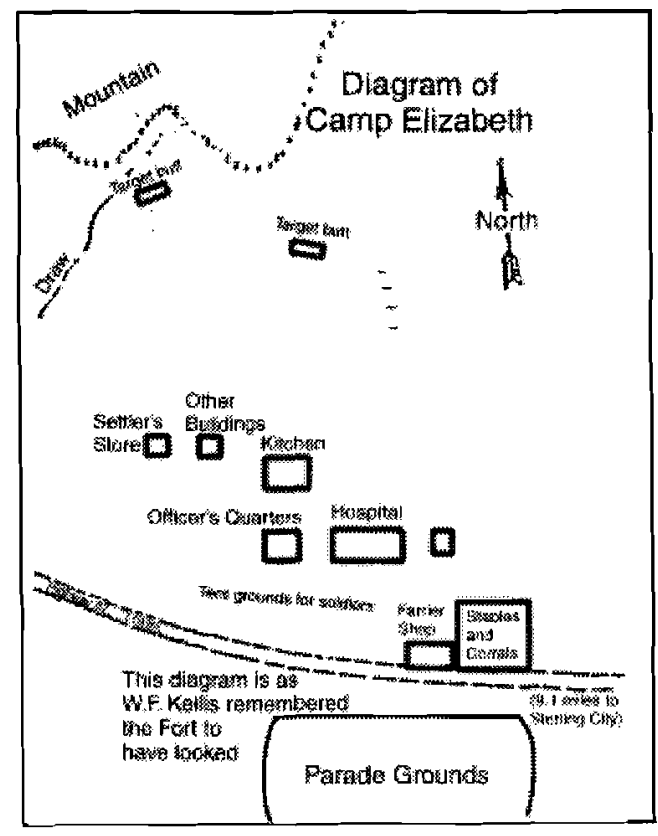

Figure 3. Sketch map of the Camp on the North Concho as remembered and drawn by a former county surveyor. 


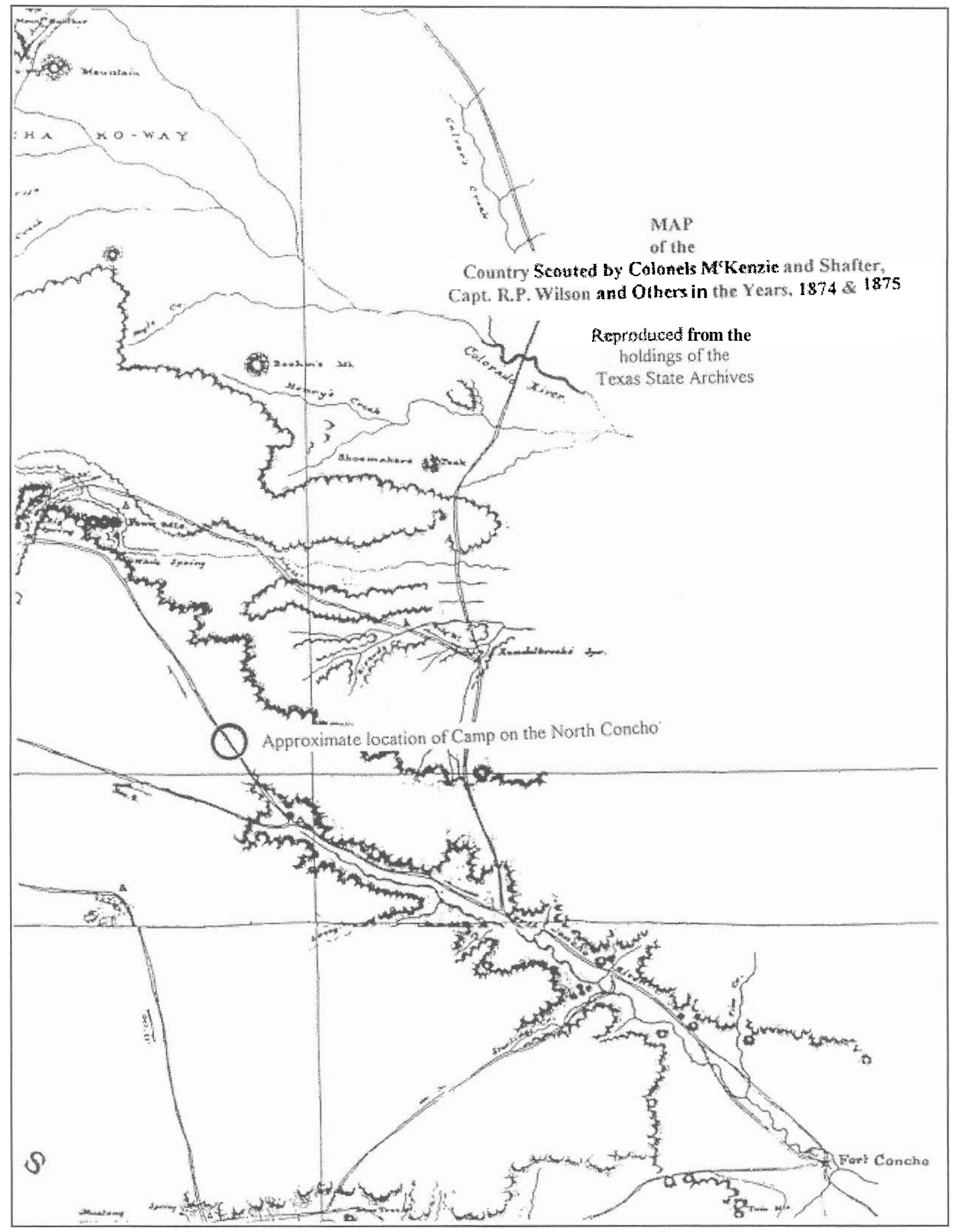

Figure 4. 1875 map of trails leading west from Fort Concho, including one that passed through the Camp on the North Concho (from the holdings of the Texas State Archives). 


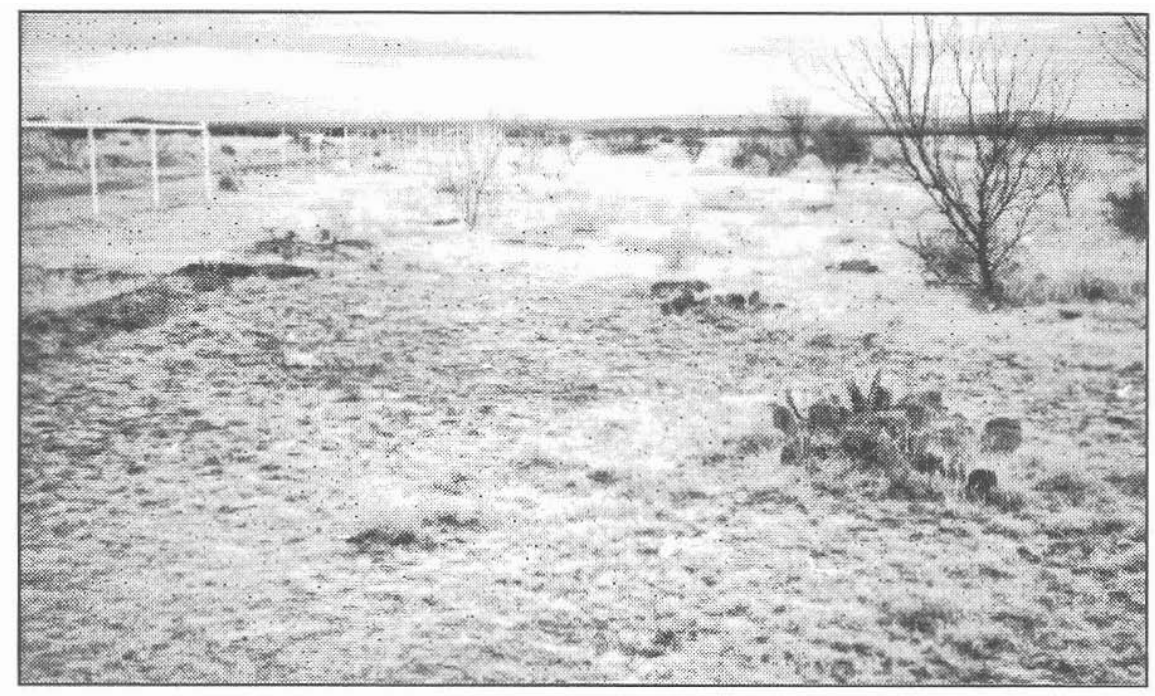

Figure 5. View of the Camp on the North Concho as it appears today.

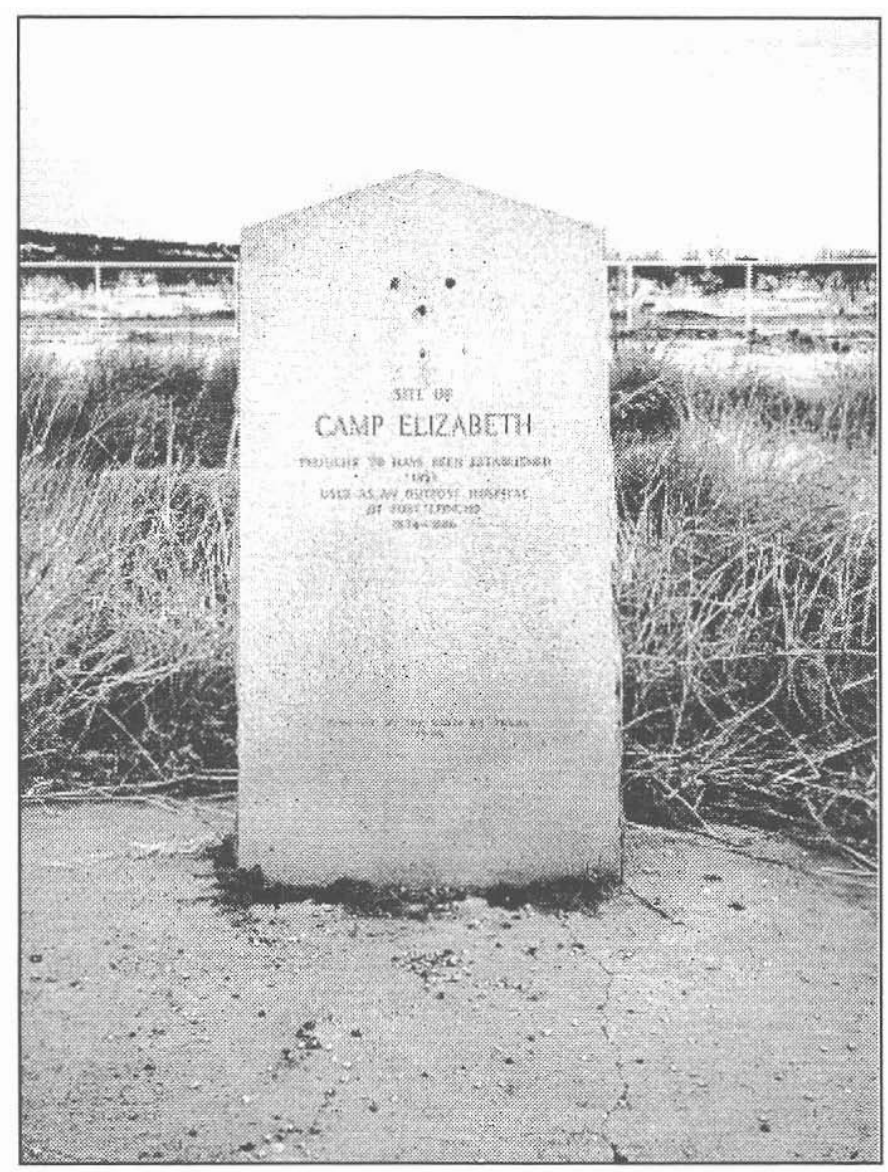

Figure 6. The 1936 State of Texas Centennial Marker for the Camp on the North Concho located on the north side of U.S. 87. 


\section{Field Methods}

In February and March 1997, an archeological survey of ca. three miles of U.S. 87 was completed and the remains of the Camp on the North Concho were mapped and evaluated for the National Register. The survey was completed by Daymond Crawford March 12-14, 1997. It consisted of a pedestrian survey of the new right of way on the north side of present US 87. The new right of way had been previously fenced and/or marked by survey stakes, making it visible during the surface survey. Because less than 20 percent of the ground surface is covered by forbs and grasses, exploratory shovel tests to identify cultural resources were not employed to search for sites. The cut banks of McEntire Draw, which roughly flow perpendicular (northeast to southwest) to US 87, was inspected for cultural deposits. McEntire Draw is generally heavily incised and no cultural materials were noted in its cut banks. However, a sparse concentration of lithic debitage was present on the south ridge above the draw. This area, while sparse, stood out from the occasional flake noted elsewhere in the survey area. Hence, it was recorded as site 41ST110. No collections were made.

On February 2-4,1997, the remains of Camp on the North Concho were mapped and recorded by Nancy Kenmotsu and Daymond Crawford of TxDOT's
Environmental Affairs Division and Nancy Fisher of TxDOT's San Angelo District office. Early in the planning process, the San Angelo District Office had noted that this portion of U.S. 87 contained the remains of the Camp on the North Concho, known locally as "Camp Elizabeth" (Dearen n.d.). A Texas Centennial marker was placed at the site in 1936 (see Figure 5), and there is a paved pull out on U.S. 87 to allow the traveling public to read the marker. Known to have began as a Texas Ranger encampment, and to have later served as an outpost for Fort Chadbourne and Fort Concho, archeologists from Environmental Affairs developed a methodological approach for recording and assessing the remains of the Camp on the North Concho (41ST111)in consultation with staff at the district office and the Texas Historical Commission (Weaver et al. 1997).

The methodology employed at 41ST111 consisted of mapping the portion of the site in our right of way with a plane table and alidade, and individually mapping each feature (Figure 7). The plane table was placed in the northcentral area of the portion of the camp that is within new right of way. Since survey stations established by the department's survey team were too distant, a temporary datum was established on the fence erected along the north edge of the new right of way. Because the area mapped is

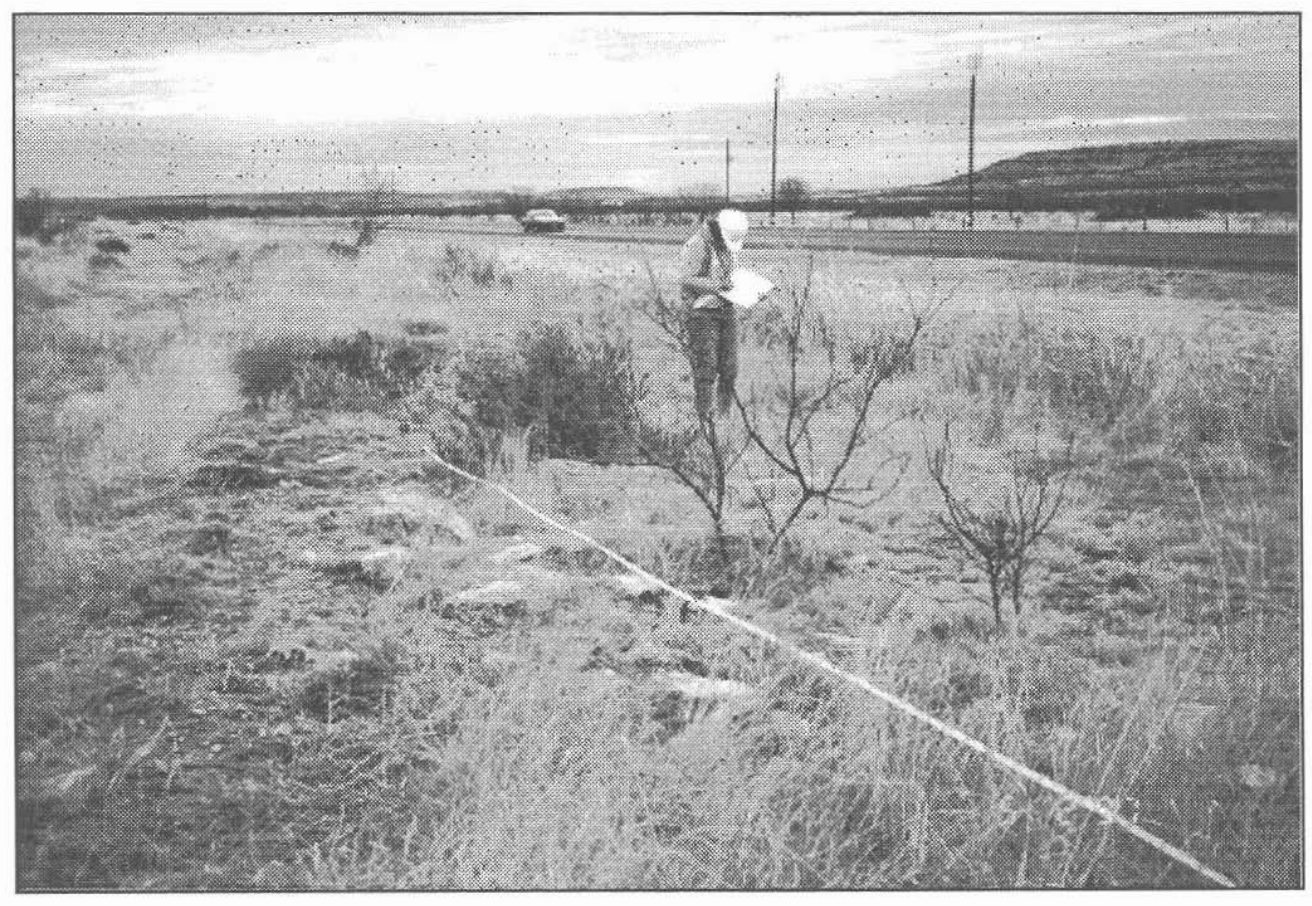

Figure 7. Mapping Feature 1 at the Camp on the North Concho 
relatively small ( $120 \times 60$ meters), and because there is little vegetation, mapping was completed from a single station. No work was completed, nor was access obtained, to the portions of the camp north of the right of way.

During site mapping, concentrations of limestone chunks that appeared to be roughly shaped into rectangular and/or sub-rectangularblocks and measuring 10 to $80 \mathrm{~cm}$ in length were noted and mapped as features 1 through 5. The 1936 Centennial marker and all disturbances to the site (including the turnout, the concrete marker pad and two fire lanes) were also mapped with the alidade and stadia rod. After completion of the site map, each individual feature was mapped in greater detail using a 30- meter tape and a 6- meter measuring rod. All limestone chunks that defined a feature were measured and drawn to scale.

In addition to mapping, a metal detector was used to determine if any concentrations of metal might be associated with the feature. When the metal detector was first employed, it was placed at its highest setting. The auditory and counter readings were so continuous that it was clear that metal is ubiquitous across the site. To compensate for the high frequency, the metal detector setting was reduced by one half to screen out smaller concentrations of metal. This allowed the operators to pinflag concentrations at and surrounding the features. Those concentrations were delineated on feature maps with the exception of those at Feature 1. Feature 1 is bordered on its north and south sides by disturbances that would have obliterated the integrity of any concentrations. The metal detector was, however, passed over the feature itself, and verified that metal was indeed present.

Two historic artifacts were collected during the field effort. Both were plotted in situ during the feature mapping. They were placed in paper sacks with their provenience and returned to Austin for photographing and curation. The artifacts will be permanently curated at the Fort Concho Historic Site, a facility owned and operated by the City of San Angelo with a full time curatorial/ archeological staff.

At the conclusion of the field effort, historic archival investigations were completed by John W. Clark. These investigations included research in the Texas State Archives and elsewhere to estimate the volume of information available at each repository. Historic maps at the Texas General Land Office and aerial and soils maps on file at the Texas Natural Resource Information Systems were also researched as part of this effort. 


\section{RESUlts OF THE INVESTIGATIONS}

TWOarcheological sites were recorded and assessed during this effort. One of the sites (41ST111) is the historic site of the Camp on the North Concho; the other site is a lithic scatter located on the upland surfaces of an eroded ridge that overlooks McEntire Draw. This lithic scatter contains primary and secondary reduction flakes, but with shallow deposits averaging less than $10 \mathrm{~cm}$ in depth. The shallow depth of the site and its lack of features have resulted in an assessment that it does not contain information that will contribute to our understanding of prehistory. Therefore, we conclude that it is not eligible for the National Register and does not warrant further work. The Camp on the North Concho is concluded to be eligible for the National Register and is recommended for mitigation prior to construction, and is described below.

Site 41ST111 is the Camp on the North Concho. A small portion of the camp is within the right of way of U.S. 87; the site extends north toward McIntyre Butte and south to the North Concho River. The camp is known to have been located on a route used for travel since at least 1874 (see Figure 4). It is probable that this travel route predates 1874 since the site was also an encampment for the Texas Rangers as early as the 1850s (Dearen n.d.:123). Present U.S. 87 was constructed ca. 1939 andimpacted the southern portion of the site. A 1954 aerial photograph of the site indicates an earlier alignment of the road that roughly parallels U.S. 87 to the north (Figure 8). This older alignment may represent an earlier 20th century version of U.S. 87, or the road depicted on Shafter's 1875 map. Since the map prepared by the county surveyor indicates that an earlier version of U.S. 87 cut just south of the stables/corrals, farriershop and tent ground for soldiers (see Figure 3), the road is likely the early 20thcentury road. If correct, when present U.S. 87 was constructed just to the north of the old alignment, it impacted some or all of these features.

Within the right of way, the camp consists of five concentrations of shaped limestone blocks that were recorded as features (Figure 9). Other, more substantial features are present north of the right of way and can be seen on a 1995 aerial photograph (Figure 10). This recent photograph also shows a large sub-circular anomly and several smaller anomlies south of U.S. 87. The large subcircular anomly resembles the shape of the parade ground shown in Figure 3. The only vegetation on the site consists of small forbs and grasses and a few small mesquite and prickly pear cacti. A few artifacts are visible, hut the metal detector indicated that many more are present below the surface. Years of visitation (and collecting) by the traveling public may have resulted in the few artifacts visible on the surface.

Feature 1 is an area of large and small limestone rocks, and is the most prominent feature within the right of way. It is bordered on its northern margin by a fire lane maintained by the former landowner, and on its southern margin the former right of way fence (Figure 11). Both of these disturbances were bulldozed to ca. $15 \mathrm{~cm}$ and do not contain artifacts or cobbles. Metal detector passes over the firelane did not reveal subsurface metal artifacts. Within Feature 1, however, the metal detector hits were so continual that the results were not plotted. The limestone rocks have evidence of being shaped into quasirectangular or square blocks. Most are tabular. While bedrock in the region is this same white-colored limestone, these blocks were hrought to the site, likely from the slopes of McIntyre Butte, located ca. 400- meters north of the site. The naturally occurring limestone cobbles at the Camp on the North Concho are small (less than 5 - cm diameter), alluvial, rounded cobbles. These vary from ca. 25 - to $70-\mathrm{cm}$ diameter. Feature 1 may have been larger at one time, prior to erection of the old right of way fence and the fire lane. It is tentatively concluded that Feature 1 represents the remains of the farrier's shop depicted on the surveyor's map.

Feature 2 is a highly dispersed group of less than 20 limestone rocks (Figure 12). located just east-southeast of the alidade and plane table station. As with Feature 1, these cobbles appear quasi-shaped and were hrought to this location, most likely from McIntyre Butte. Most average $15-\mathrm{cm}$. diameter. None exceed $25 \mathrm{~cm}$ and most are tabular in cross section. Metal detection on and around Feature 2 resulted in identification of an intense concentration of metal in the southwestern perimeter of the feature. Other areas of the feature also had metal concentrations, as shown on Figure 12, but were of lesser magnitude than the southwestern perimeter. A metal button was noted in the western portion of the feature and was collected (Figure 13). While the function of Feature 2 map is not known, it is within the area depicted on the surveyor's map as "area of tent structures" (see Figure 3).

Feature 3 is situated ca. 20 meters west of Feature 2 (see Figure 9). Feature 3 is another dispersed group of limestone cobbles that appear to have been shaped. Most rocks are under $20 \mathrm{~cm}$. in diameter and sit on the modem ground surface. These rocks do not form any apparent shape, but were recorded as a feature because they are generally closer to each other than to anything else at the camp and because they are not naturally occumng in the soil. Metal detection of Feature 3 confirmed it as cultural. A large void with only a few isolated hits is present between features 2 and 3. At Feature 3, the hits increase; 


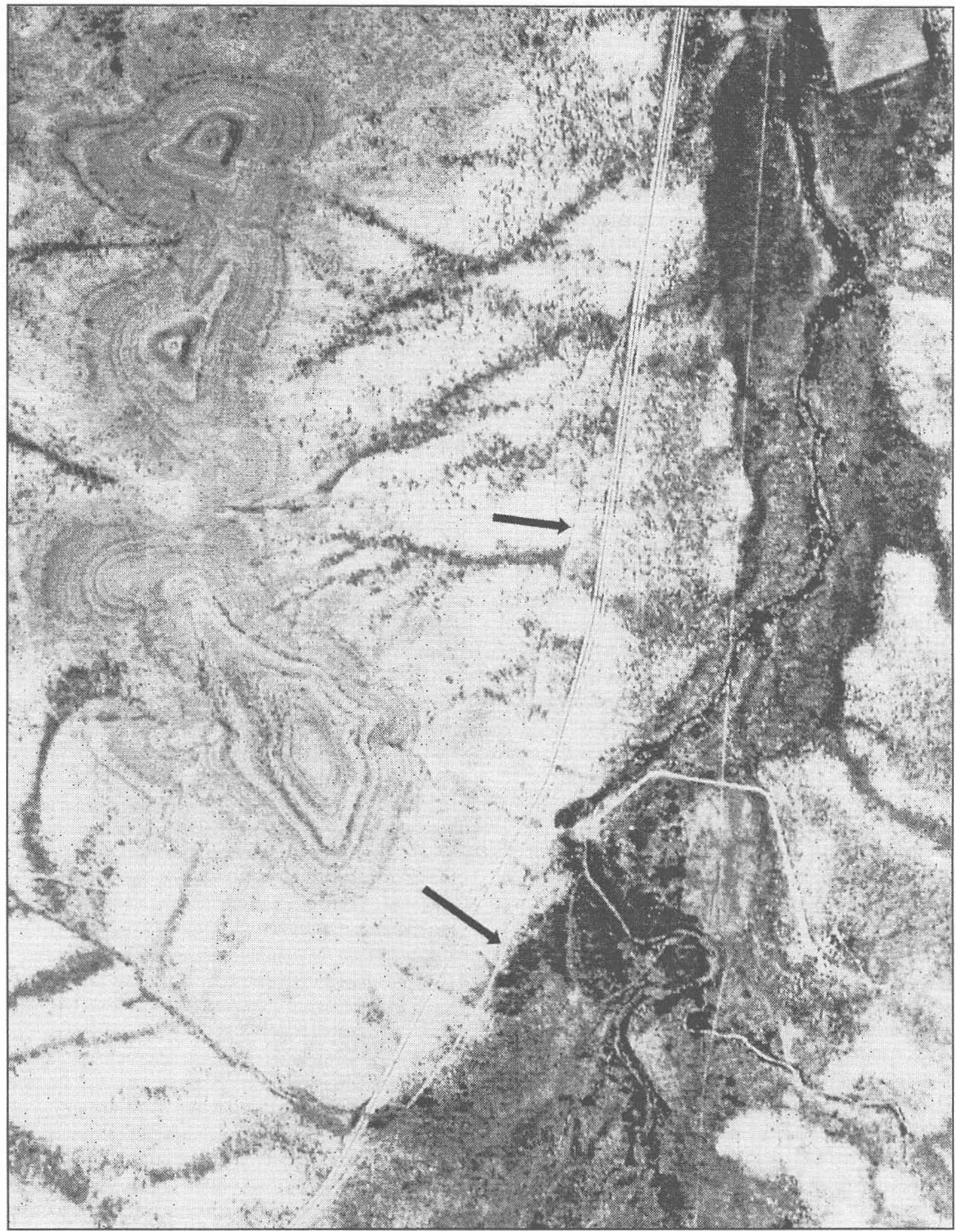

Figure 8. 1954 aerial of the area of the Camp on the North Concho (see arrow) showing an earlier alignment of U.S. 87 (from the holdings of the Texas Natural Resources Information System). 


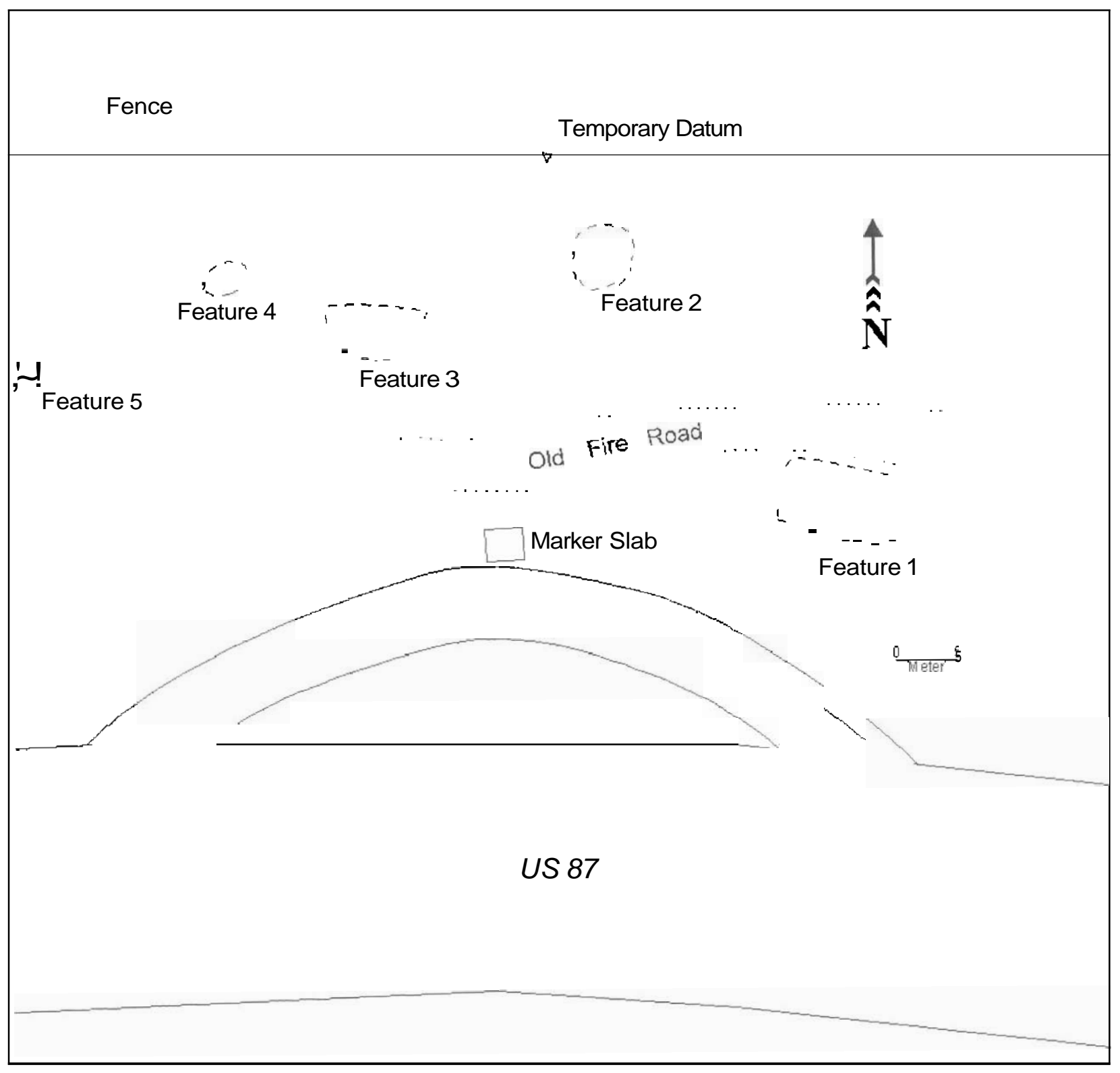

Figure 9. Map of the Camp on the North Concho, 41ST111. 


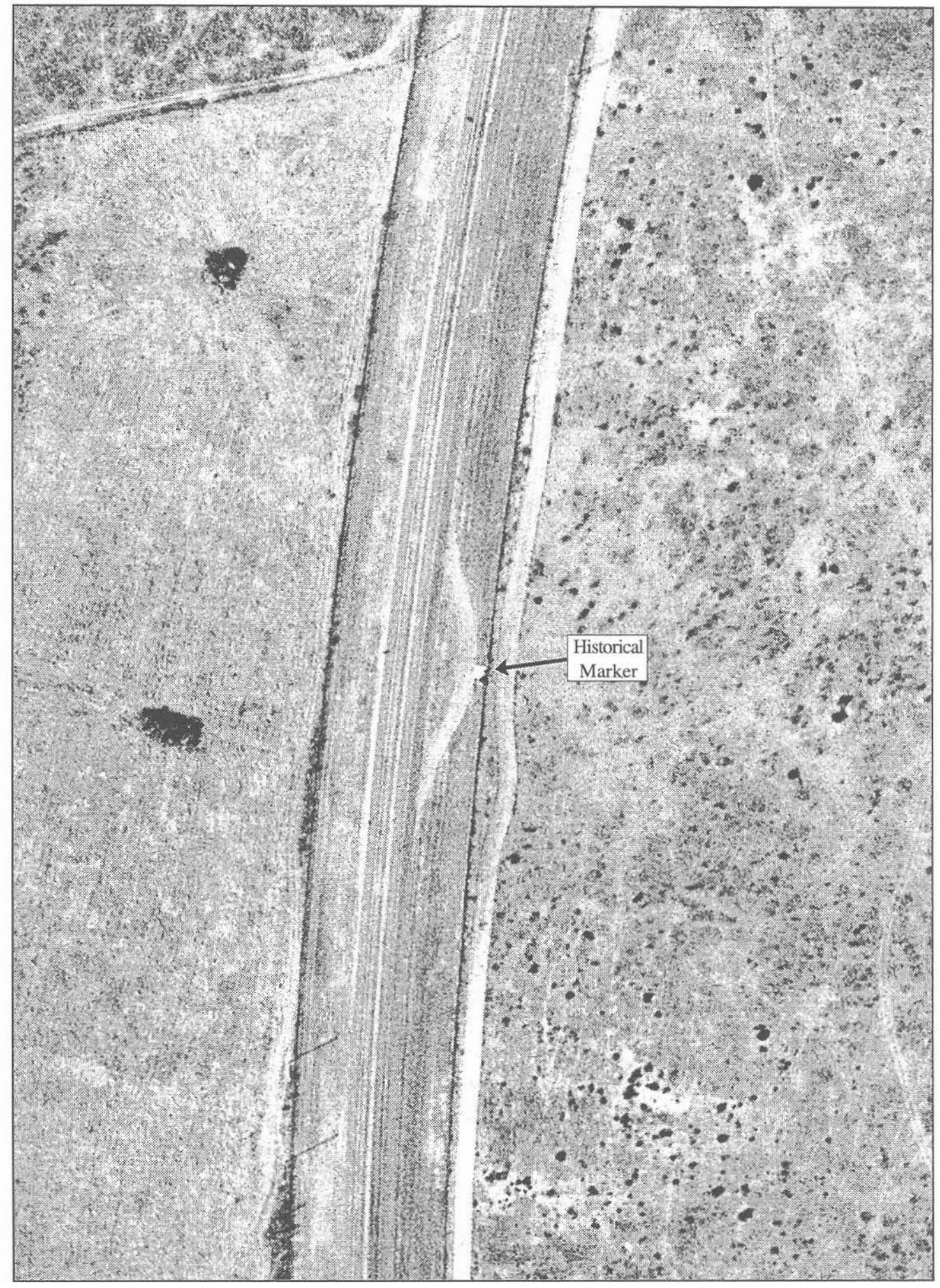

Figure 10. 1996 aerial photograph of $415 T 111$ (courtesy San Angelo District,Texas Department of Transportation) 


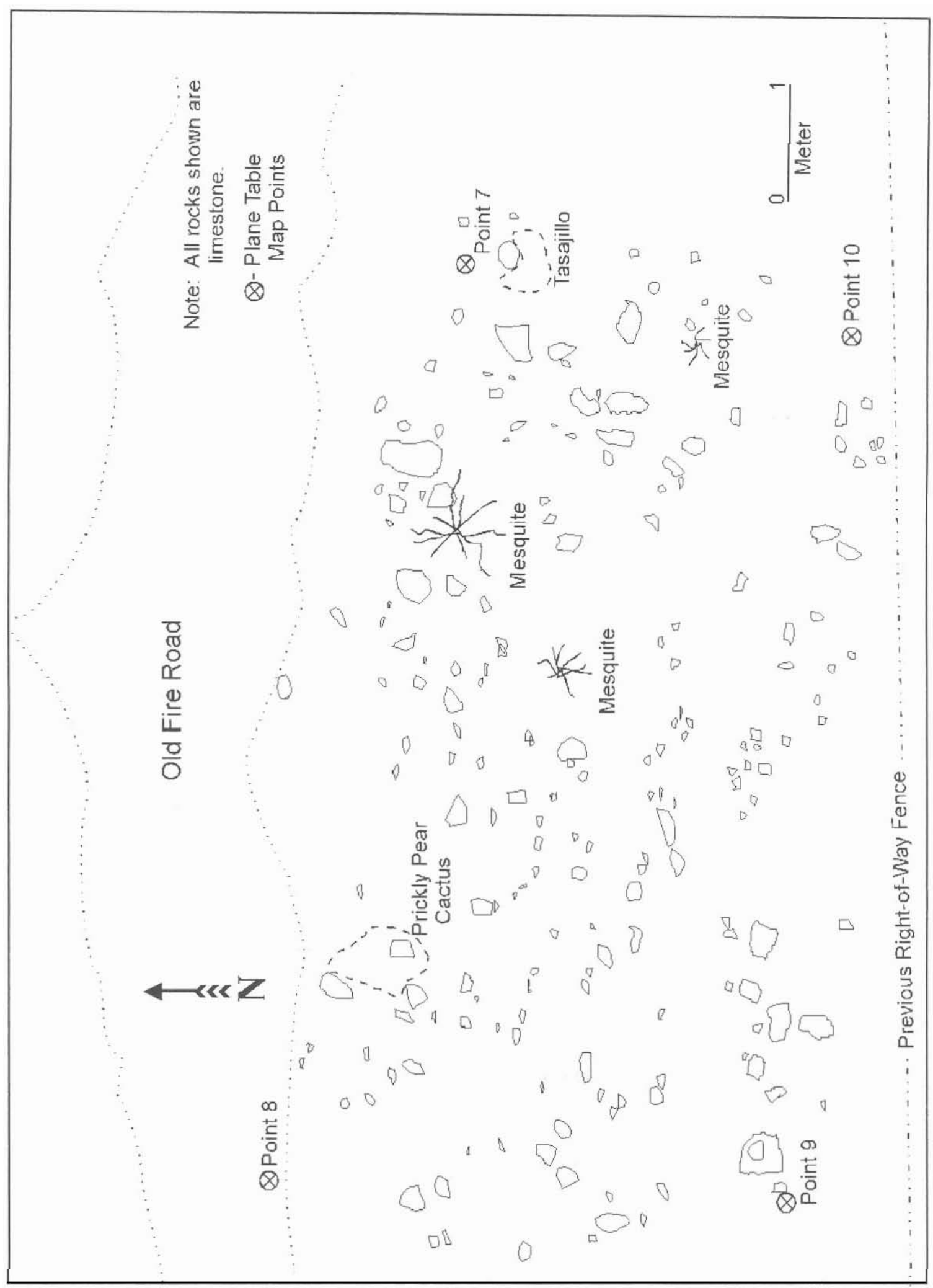

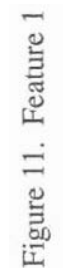




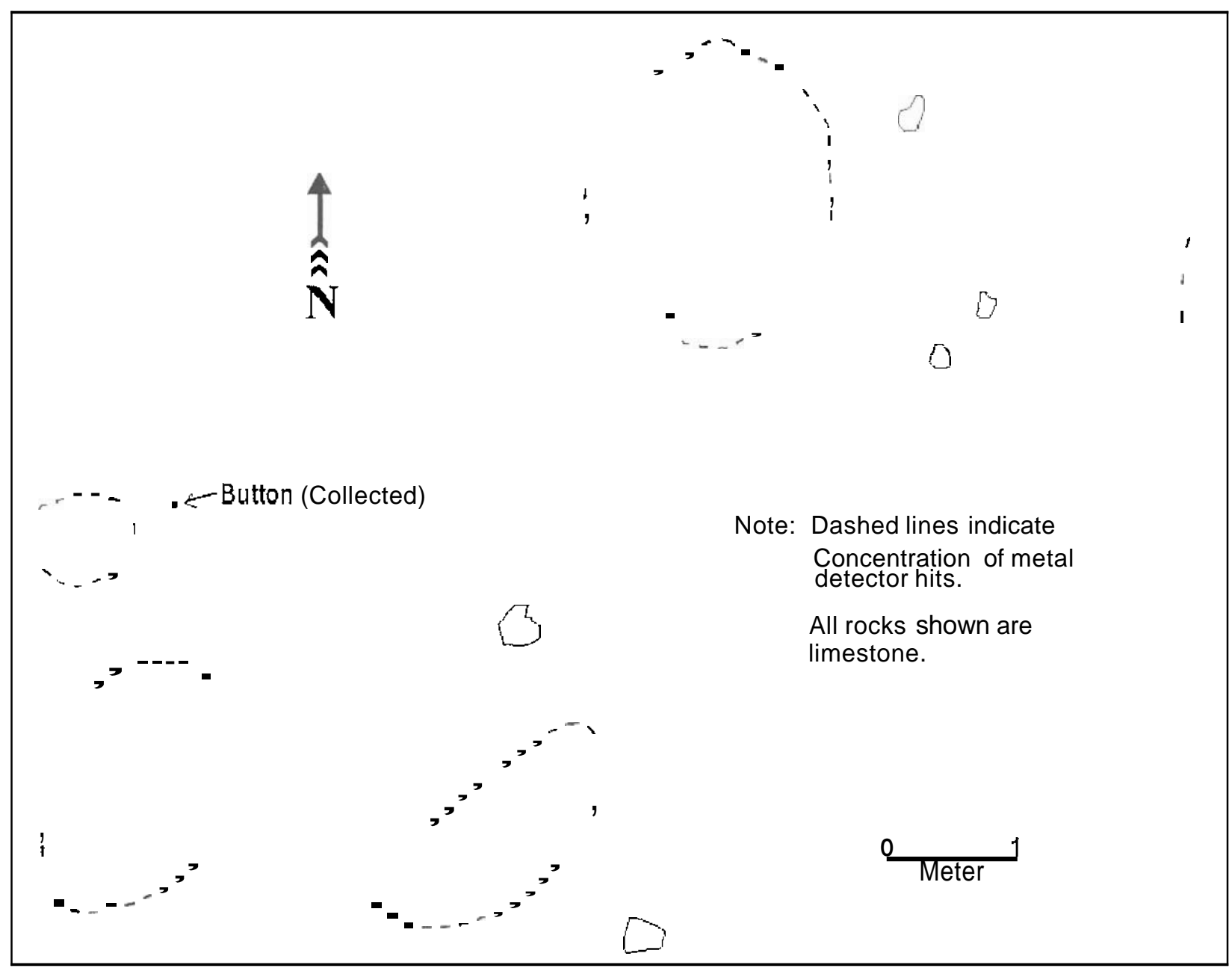

Figure 12. Map of Feature 2.

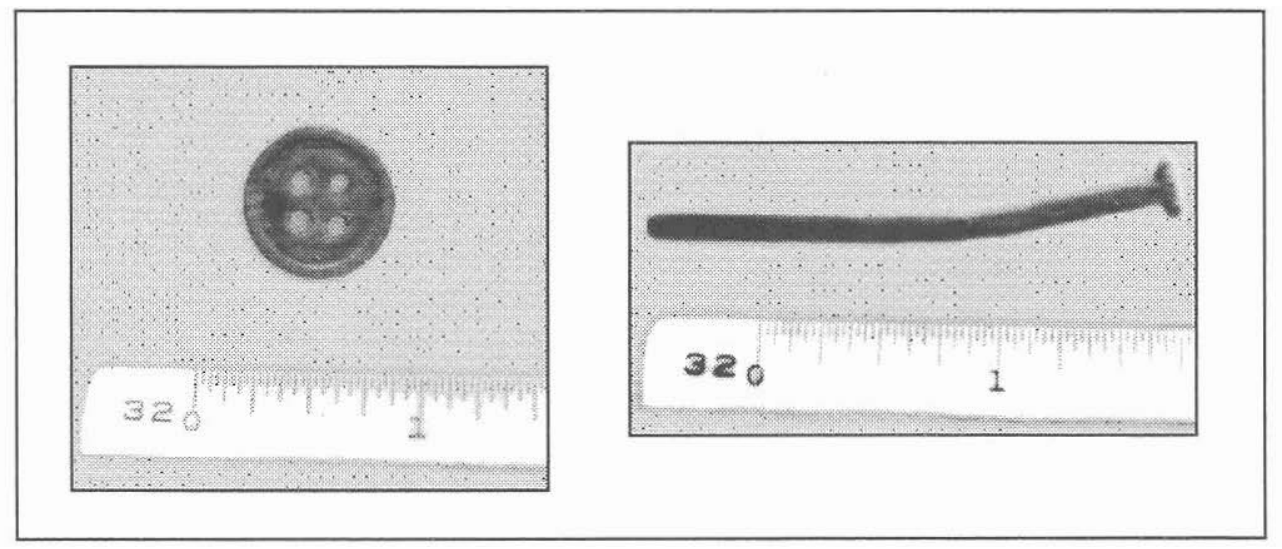

Figure 13. Artifacts collected from the Camp on the North Concho: a) metal button from Feature 2:b) square nail from Feature 3. 
some are quite heavy. Three cut nails were noted on the western margin of Feature 3. All three are in markedly good condition, and one was collected (see Figure 12). While the function of Feature 3 is uncertain, it is within the area depicted on the surveyor's map as "area of tent structures" (see Figure 4).

Feature 4 is located ca. 8 meters west of Feature 3. Again, it is a dispersed group of rocks from nearby limestone outcrops, and roughly shaped. Some are tabular in cross-section. Dispersal of these rocks is less obvious than in Feature 3. Most are adjacent to an area of slightly higher $(\mathrm{ca} .5-8 \mathrm{~cm}$ ) soil that contains a small mesquite tree and a tasajillo bush. It is possible that additional rocks are buried beneath this hummock. Again, the metal detector indicated a concentration around the feature, mostly on the eastern half. While the function of Feature 4 is uncertain, it is within the area depicted on the surveyor's map as "area of tent structures" (see Figure 4).

Feature 5 is the most westerly of the features that were defined and is located on the western edge of the site. If the camp extended west of Feature 5, it was not detected either visually or with the metal detector. Feature 5 is quite small, consisting of only four limestone rocks (see Figure 9). One is relatively large and partly buried; the others are sitting on the ground surface. Metal detector hits were fewer around Feature 5, and were isolated hits rather than the intense, repetitive hits recorded for other features. While the function of Feature 5 is uncertain, it is within the area depicted on the surveyor's map as "area of tent structures" (see Figure 4).

Limited archival documentation was completed as part of this effort. Much of the data gleaned during that effort is incorporated into the descriptions above.

However, Appendix I contains a summary of the source material available on Fort Concho and its Camp on the North Concho. Source material believed to be related to these two installations are specified for each archive and/ or location. 


\section{Summary and Recommendations}

Archeological investigations were carried out along three miles of proposed improvements to U.S. 87. The survey was carried out as part of TxDOT's compliance with the Antiquities Code of Texas and the National Historic Preservation Act. Fieldwork and reporting conform to the requirements of TxDOT's MOU with the Texas Historical Commission (THC) and with the Programmatic Agreement signed by the THC, the Advisory Council on Historic Preservation, the Federal Highway Administration and TxDOT. The investigations resulted in the recording of two sites. One of the sites (41ST110) is a scatter of lithics that is concluded not to meet the criteria for inclusion in the National Register of Historic Places. No further work is recommended for this site.

The investigations also resulted in the recording, mapping and assessment of site 41ST111. This site is the remains of an encampment of Texas Rangers that later became the Camp on the North Concho, an outpost of Fort Chadbourne and later Fort Concho. A portion of those remains are within the right of way of U.S. 87. As noted above, Fort Concho and the camp were part of a frontier system designed to protect and extend Anglo-American settlement in Texas westward. After the Civil War, the system was built and maintained by African-Americans, whom the Indians called Buffalo Soldiers. While this westward movement was guaranteed to conflict with Native American ownership of the lands, the movement and the system that sustained it represent an important part of the history of Texas. Moreover, the camp was largely staffed and used as training for African-American soldiers, whose participation and importance in the westward movement has received only limited study (Leckie 1967). Therefore, the Camp on the North Concho is concluded to meet Criterion A for the National Register. Because the portion of the camp within the right of way has intact features and because no other U.S. Army camps of Buffalo Soldiers have been subjected to archeological investigation, the camp is also concluded to meet Criterion D.

The recommendations for mitigating the effects of the proposed upgrading of U.S. 87 on the Camp on the North Concho include both archeological and archival investigations. The archeological recommendationscall for limited subsurface investigations of the area mapped during this evaluation, with a greater effort to focus on obtaining information related to the camp occupants (particularly the Buffalo Soldiers). Archival investigations are recommended to consist of an effort 1) to briefly search for material related to use of the camp by the Texas Rangers, 2) to understand the role of the camp as an outpost for Forts Chadbourne and Concho, and 3) to investigate the training and duties of the Buffalo Soldiers at the camp. Finally, a brochure on the Camp on the North Concho, based on the archival and archeological studies, will be developed. Specific details of the mitigation are listed below:

I. Archeological Mitigation: Given the objective of archeological investigation, it is recommended that fieldwork at the site will be devoted to obtaining a representativesample of the artifactual material present and to create an improved base map. The following tasks will accomplish this objective and are expected to take no longer than one week.

A. Map the portion of the camp in the right of way with a transit or total data station and establish a 10- meter grid across the right-of-way. The grid should be placed to ensure that excavation units are situated in or adjacent to features 2-5.

B. Excavate $7250 \times 50 \mathrm{~cm}$ units in the southwest comer of each of the gridded units, screening and collecting all artifacts. Since it is expected that the deposits will not exceed $15 \mathrm{~cm}$ in depth, and since it is unlikely that they are stratified, each unit can be excavated as a single unit.

C. Excavate four $50 \times 50 \mathrm{~cm}$ units at Feature 1 to confirm its use (or not) as the farrier's shop.

D. Gradall excavate the remaining area of the site in the right-of-way, recording and mapping any features identified.

E. Analysis, conservation and curational preparation of all artifacts in accordance with the standards and requirements of Fort Concho National Historical Site.

II. Archival Mitigation: The archival effort is recommended to focus on the role of the camp as an outpost for two historic forts and the training of Buffalo Soldier troops at the site. Some effort will also be expended to determine if the camp was used by the Texas Rangers. The archival effort will be expected to concentrate on the materials specified in Appendix I. The following tasks will accomplish this objective and are expected to require five weeks.

A. Investigate materials on the Texas Rangers at the Texas State Archives. The effort would include a search of the materials on file related to Texas state troops and militia to confirm (or not) the use of the camp by the Rangers. Time is 
estimated to be one week.

B. Investigate the Hunt and Grierson papers on file at Fort Concho. These papers may contain valuable references to the camp and its training detail, and will certainly contain general information about the Buffalo Soldiers and their role in maintaining the westward expansion. Time is estimated to be one week.

C. Investigate materials from the National Archives (Fort Worth and Washington,D.C.) related to forts Concho and Chadbourne and the camp. While it is anticipated that this will include the archives in Fort Worth and Washington, D.C., Fort Concho may have copies of information from the National Archives. If so, more time would be spent at Fort Concho and less at the National Archives. The effort would also be concerned with general information about the Buffalo Soldiers. The Fort Worth archive has many records on microfilm and may be able to borrow microfilm from Washington. Time is estimated to require two weeks in Fort Worth and one week in Washington, D.C.
At the conclusion of the archival and archeological investigations, a report detailing information related to the research issues listed above (i.e., identification of the camp's occupants, the training carried out at the camp, and the role of the camp and the Buffalo Soldiers in maintaining and sustaining westward expansion in Texas) will be completed. The report will conform to the Council of Texas Archeologists reporting standards, as well as those of the Secretary of the Interiors Standards and Guidelines: Archaeology and Historic Preservation. Aminimum of 20 copies of the report will be provided to each of the following: Texas Historical Commission, Fort Concho, Fort Davis, Fort Clark, the Institute of Texan Cultures and the Texas State Library. In addition, a brochure on the camp and its role in Texas history will be developed in consultation with the staff of Fort Concho National Historic Site. TxDOT will print 5,000 copies of the brochure for distribution at Fort Concho, Fort Davis, and in TxDOT's Travel and Information Centers. A copy of the paste-up of the original brochure will be provided to Fort Concho for subsequent printings. 


\section{References Cited}

AGN (Archivo General de la Nacion)

1683 Provincias Internas 37. Expediente 4. Correspondenciadel Gobernador Domingo Gironza Petris de Cruzante al Virrey. Copy on file Nettie Lee Benson Latin American Library, The University of Texas at Austin.

Barnforth, Douglas B.

1987 Ecology and Human Organization on the Great Plains. Plenum Press. New York.

Barnes, Virgil E.

1976 Geologic Atlas of Texas, Brownwood Sheet. Bureau of Economic Geology, The University of Texas at Austin.

Black, S.L.

1989 South Texas Plains. In From the Gulf to the Rio Grande: Human Adaptation in Central, South and Lower Pecos, Texas, by T.R.

Hester, S. L. Black, D. G. Steele, B. W. Olive, A. A Fox, K. Reinhard, and L. C. Bement, pp. 39-62. Research Series No. 33, Arkansas Archeological Survey, Fayetteville.

Blum, Ervin L.

1977 Soil Survey of Sterling County, Texas. Soil Conservation Service, Department of Agriculture, Washington, D.C.

Collins, Michael B. et al.

1977 Wilson-Leonard, An 11,000-year Archeological Record of Hunter-Gatherers in Central exas. Studies in Archeology, Texas Archeological Research Laboratory, The University of Texas at Austin, and Contract Reports in Archeology No. 2, Environmental Affairs Division, Texas Department of Transportation, Austin.

Creel, Darrell

1990 Excavations at 41TG91, Tom Green County, Texas 1978. Texas State Department of Highways and Public Transportation, Highway Design Division, Publications in Archaeology, Report No. 38, Austin.
Dearen, Patrick

n.d. Portraits of the Pecos Frontier.

Daniels, Beverly (editor)

1976 Milling Around Sterling County: A History of Sterling County. Staked Plains Press, Inc. Canyon, TX.

Diamond, D.D., D. H. Riskind, and S. L. Orzell

1987 A Framework for Plant Community Classification and Conservation in Texas. The Texas Journal of Science 39:203-221.

Hammond, George P. And Agapito Rey (translators and editors)

1929 Expedition into New Mexico Made by Antonio de Espejo in 1582-1583, as Revealed in the Journal of Diego Perez de L uxan, a Member of the Party. Vol. I, Quivera Society Publications, Quivera Society, Los Angeles.

Hardin, Stephen and Richard Hook

1991 The Texas Rangers. Osprey Publishing,Ltd. London.

Henderson, Jerry

1996 Report of Survey, U.S. 87, Sterling County, Texas. Archeology Studies Program, Environmental Affairs Division, Texas Department of Transportation,Austin.

Jones, Oakah L., Jr.

1988 Nueva Vizcaya, Heartland of the Spanish Frontier. University of New Mexico Press, Albuquerque.

Johnson, LeRoy

1994 The Life and Times of Toyah-Culture Folk, As Seen from the Buckhollow Encampment, Site 41KM16, of Kimble County, Texas. Office of the State Archeologist Report 38, Texas Department of Transportationand the Texas Historical Commission, Austin.

Johnson, LeRoy and Glenn T. Goode

1994 A New Try at Dating and Characterizing

Holocene Climates, as Well as Archeological Periods on the Eastern Edwards Plateau. Bulletin of the Texas Archeological Society 65:1-51. 
Kavanagh, Thomas W.

1986 Political Power and Political Organization: Comanche Politics, 1786-1876.

Unpublished Ph.D. dissertation, Department of Anthropology, University of New Mexico, Alburqueque.

Kenmotsu, Nancy Adele

1994 Helping Each Other Out, a Study of the Mutualistic Relations of Small Scale

Foragers and Cultivators in the La Junta de los Rios Region, Texas and Mexico. Unpublished Ph.D. dissertation, Department of Anthropology, University of Texas at Austin.

Kenmotsu, Nancy A., Timothy K. Perttula, Patricia Mercado-Allinger, James E. Bruseth, Sergio Ireguas and Curtis Tunnel1

1994 Archeological and Documentary Research at Medicine Mounds Ranch, Hardeman County, Texas. Cultural Resource Management Report 4, Department of Antiquities Protection, Texas Historical Commission, Austin.

Leckie, William $\mathrm{H}$.

1967 The Buffalo Soldiers: A Narrative of the Negro Cavalry in the West. University of Oklahoma Press, Norman.

Opler, M orris

1983 The Apachean Cultural Pattern and Its Origins. In Handbook of North American Indians, The Southwest, Vol. 10, edited by Alfonso Ortiz, pp. 368-392. Smithsonian Institution Press, Washington, D.C.

Quigg, J. Michael and Jay Peck

1995 The Rush Site (41TG346)A Stratified Late Prehistoric Locale in Tom Green County, Texas. Technical Report No. 816C, Mariah Associates, Inc., Austin.

Rister, Carl Coke

1986 Fort Griffin on the Texas Frontier. University of Oklahoma Press, Norman.
Saunders, Joe W., C. S. Mueller-Wille,S. Carlson, R. Korgel, R. Pearson and H. B. Ensor

1991 An Archeological Survey of the Proposed South Bend Reservoir Area, Young, Stephens, and Throckmorton Counties, Texas. Archeological Survey Number 6, Texas A\&M University, Archeological Research Laboratory, College Station.

Sellards, E.H.

1936 Recent Studies of Early Man in the Southwestern Part of the United States. American Naturalist 70:361-369.

Tanguchi, Alan Y., Roy E. Graham and Gus C. Hamblett

n.d. Texas Historic Forts, Part V, Richardson. Texas Parks and Wildlife Department. Austin.

Terrazas Sanchez, Filiberto

1973 La Guerra Apache en Mexico. B. CostaAmic, M exico.

Treece, Abby C., Christopher Lintz, W. Nicholas Trierweiler, J. Michael Quigg and Kevin A. Miller

1993 Cultural Resource Investigation in the $\mathrm{OH}$. Ivie Reservoir, Concho, Coleman, and Runnels Counties, Texas. Vol.IV: Data Recovery Results from Ceramic Sites. Technical Report No. 346-IV, Mariah Associates, Inc., Austin.

Weaver, William, Nancy Kenmotsu, John W. Clark and Daymond C. Crawford

1997 Scope of Work for an Intensive Archeological Survey of the Proposed New Right-of-way for U.S. 87 from the Howard County Line to State Highway 163 in Sterling County. Manuscript on file Environmental Affairs Division, Texas Department of Transportation, Austin.

Webb, Walter Prescott

1965 The Texas Rangers: A Century of Frontier Defense. The University of Texas Press, Austin. 


\section{Appendix A Assessment of Archival Research Potential}

The goal of the archival investigation during this phase of work was to estimate the potential of a variety of sources for information pertinent to the interpretation of the history of the Camp on the North Concho and its place in the broader patterns of state and national history. It was not intended to discover every possible source of information or to ferret out all information contained in any one source. Rather, this limited effort was confined to simply determining if a source was likely to contain some relevant information. Since several levels of information may be of interest in any final report engendered by the proposed highway project, the annotated sources listed below include general background material, regimental history and regimental and post returns. If it is possible to identify individual soldiers who served at the camp, genealogical investigations on certain soldiers may be deemed appropriate.

The sources relate to the topics that have been selected for mitigation efforts, specifically: identification of whether or not the Texas Rangers utilized the site, the role of the camp in the protection of western settlements, the training that was given at the camp, and the Buffalo Soldiers. Each general topic is divided into general and primary source material. The general sources have no information specific to the Camp on the North Concho and only general information on Fort Concho. However, these materials provide a broader background than can be obtained by focusing entirely on a single installation. Clearly, only a few companies of the Tenth Cavalry served at Fort Concho. The general sources listed below provide a framework to understand the history and role of the regiment.

The primary source material will provide specific information on Fort Concho and its outpost on the North Concho. Much of this material is in Washington or available at the regional center in Fort Worth. Fort Concho has copies of some of this material as well. It should be noted that requests for service records require a special form but may be ordered by mail. A detailed record of personnel and events with information on architecture, etc., should not be expected. It is likely that the information found will relate to assignments of troops to the facility for periods of time and perhaps a few medical records for troops ill or injured at the post.

The primary sources for the Texas Rangers will be found in the Texas State Archives. The documents most likely to contain information on the site on the North Concho are the monthly returns of the Frontier Battalion. The muster rolls will provide information on who served in the companies active in the area at the appropriate time. The information will not likely include data on Rangers founding a permanent post at this location. The B arry Papers at the University of Texas may have a small amount of pertinent information and have value as a firstperson account.

Primary material for the Texas State Troops are also in the Texas State Archives, although the specific assignments of troops to Fort Concho or the Camp on the North Concho may not be found. The Military Board records may hold data relating to the subject. If so, then the muster rolls will tell who served. The records of the Frontier Regiment may also contain data relevant to mitigation at 41ST111.

Since we know which regiment and which companies within the regiment served at Fort Concho after the Civil War, muster rolls will provide a list of names and service records can then be acquired for selected soldiers. If the post had a hospital as a branch of Fort Concho, the field hospital reports may contain interesting information. The regimental and post returns are the most likely documents to contain information on the Camp on the North Concho, and the documents collected on the Negro in the Military Service of the United States should provide good background material for the period.

\section{General Information: Texas Rangers}

Hardin, Stephen and Richard Hook

1991 The Texas Rangers. Osprey Publishing, Ltd. London.

This book provides a good general introduction to the history of the Texas Rangers and is well illustrated. The book is divided into time periods and discusses a general history of the Rangers for each period.

Sowell, A. J.

1964 Rangers and Pioneers of Texas. ArgosyAntiquarian Ltd. New York.

Sowell discusses numerous incidents involving Rangers. The book is a reprint of the 1884 edition and, like the original, is not indexed. 
Webb, Walter Prescott

1965 The Texas Rangers: A Century of Frontier Defense. The University of Texas Press, Austin.

Webb's book is the classic history of the Rangers in narrative form with detailed information from the earliest beginnings into the 1930s. It has an index but no mention of Camp Elizabeth, Camp on the North Concho or Buck Barry. The tome is valuable for the detailed information it provides on the Rangers.

Winfrey, Dorman H, and James M. Day 1959- Texas Indian Papers, Edited From the Original ms. Copies in the Texas State Archives. 1961 Texas State Library. Austin.

Much of the documentation in these volumes deals with the state's efforts to establish and maintain trading posts among the Indians and to establish reservations on the upper Brazos. There is relatively little information on Ranger activity.

\section{Texas Rangers Primary Sources}

The Texas State Archives is the repository for much information on the Rangers. There may also be information in the following:

Adjutant General's Office

Frontier Battalion, Monthly Returns

Rangers, pension letters

Bonds for arms \& Ranger receipts

Index to Ranger Muster Rolls

Texas State Department

Domestic Correspondence, 1846-1900

Center for American History, Archives. University of Texas

James Buckner B arry Papers

Confederate State Troops: General Sources

Miller, Thomas Lloyd

1985 Texas Confederate Scrip Grantees. Thomas Lloyd Miller. N.P.

This compilation is a list of indigent Confederate survivors and widows receiving land scrip for service. Most of the land was in West Texas, and may include areas near the Camp on the North Concho.
Oats, Stephen B.

1961 Confederate Cavalry West of the River. The University of Texas Press, Austin

Oats gives a good general overview of Confederate mounted activities in the Trans-Mississippi Department with little information specific to Texas. Fort Concho and the Camp on the North Concho do not appear in the index.

Wright, Marcus J.

1965 Texas in the War 1861-1865. The Hill Junior College Press, Hillsboro, TX.

This volume contains a wealth of information on the Confederacy in Texas, including lists of all Confederate Regiments from Texas serving in other areas and the regiments serving in Texas with their officers, biographies of officers, civilian public servants, a compilation on the vote for secession, selected correspondence, a list of major engagements in Texas, and other material.

Confederate State Troops: Primary Sources

Adjutant General's Office

State Troops, Muster Rolls 1861-1865

Frontier Regiment 1862-1864

Muster rolls, letters, reports, contracts, enlistment papers, etc.

Index to Confederate Muster Rolls

Military Board 1862-1865

\section{General InFormation: U.S. Army}

Glass, Maj. E. L. N

1972 The History of the Tenth Cavalry 18661921. The Old Army Press, Fort Collins, $\mathrm{CO}$.

As a regimental history, this volume contains detailed information about the tenth Cavalry, including lists of officers, selected regimental returns, information on the results of a variety of competitions, a list of engagements and a variety of appendices. Companies A, D, F, G, I and L served at various times at Fort Concho. There is no index and no mention of the Camp on the North Concho. 
Leckie, William $\mathrm{H}$.

1967 The Buffalo Soldiers: A Narrative of the Negro Cavalry in the West. University of Oklahoma Press, Norman.

This classic book relates the history of the 9th and 10thCavalry Regiments created for AfricanAmerican soldiers after the Civil War for use on the Indian frontier. The book is indexed but does not mention Camp Elizabeth or the Camp on the North Concho. It is a good background source and has information on Fort Concho.

Leckie, William H. And Shirley A. Leckie

1984 Unlikely Warriors: General Benjamin $\boldsymbol{H}$. Grierson and His Family. University of Oklahoma Press, Norman.

In this volume, the Leckies provide a biography and genealogy of Grierson with information on his service with the tenth Cavalry as well as his Civil War service.

Rickey, Jr., Don

1963 Forty Miles a Day on Beans and Hay. University of Oklahoma Press, Norman. In his book. Rickey discusses the post Civil War Indian frontier army including all units, white and black. It is a good source of information on life in the army and avoids an emphasis on battles.

\section{Primary Sources: U.S. Army}

National Archives and Records Service (NARS) Compiled Service Records Indian Wars in Texas 1849-51 (must have name and unit)
Medical Reports and Lists

Record Group (RG) 94 Field Hospital Reports

1821-1912 arranged under States and Territories, Army Corps, Departments and US Army

Regimental 11,000 volumes.

Registers of Enlistments

1859-70 Microfilm M233 rolls 27-37

1871-77 rolls $38-40$

1878-84 rolls 41-43

Available at Fort Worth

Returns from Regular Army Cavalry Regiments 1833-1916 (M744)

Returns from United States Military Posts $1800-$ 1916 (M617)

Available at Fort Worth

Register of the Records of the Proceedings of the U.S. Army General Courts-Martial

M1105 roll 7 (1869-83)

The Negro in the Military Service of the United

States, 1639-1886 (M858)

Compilation of records for use in a published work roll 5 Regular Army 1866-86 Available at Fort Worth

Historical Information Relating to Military Posts and Other Installations, ca. 1700-1900 M661 available at Fort Worth

RG 108 Headquarters of the Army Roster of Troops 1866-79 arranged by military district. Division or Department. Must know unit and time to search.

\section{Fort Concho}

Hunt's papers

Grierson's letters (microfilm) 